\title{
Study of Trace Ions in Wet Deposition of an Industrial Site in Monterrey's Metropolitan Area, Mexico
}

\author{
Evangelina Ramírez-Lara1, Rosa María Cerón-Bretón², Julia Griselda Cerón-Bretón², \\ Ulrico López-Chuken ${ }^{1}$, Jonathan Kahl ${ }^{3}$ \\ ${ }^{1}$ Facultad de Ciencias Químicas, Universidad Autónoma de Nuevo León, San Nicolás de los Garza, México \\ ${ }^{2}$ Facultad de Química, Universidad Autónoma del Carmen, Ciudad del Carmen, México \\ ${ }^{3}$ Department of Mathematical Science, University of Wisconsin-Milwaukee, Milwaukee, USA \\ Email: jceronbreton@pampano.unacar.mx
}

Received 10 November 2015; accepted 11 January 2016; published 14 January 2016

Copyright (C) 2016 by authors and Scientific Research Publishing Inc.

This work is licensed under the Creative Commons Attribution International License (CC BY).

http://creativecommons.org/licenses/by/4.0/

(c) (i) Open Access

\section{Abstract}

The chemistry of rainwater has been subject to numerous investigations during the last two decades due to the increase of environmental problems caused by the acid deposition. The present study focuses on one aspect of air pollution, the chemical composition of wet deposition of an industrial zone. The sampling period was from March to December 2009. The station was located on the roof of the Chemistry School at the University of Nuevo León, an area in the north of Monterrey where the majority of pollution is generated. Twenty-five wet precipitation samples were collected with an automatic sampler and analyzed for $\mathbf{p H}$, ions $\left(\mathrm{SO}_{4}^{2-}, \mathrm{NO}_{3}^{-}, \mathrm{Cl}^{-}, \mathrm{Ca}^{2+}\right.$, $\mathrm{Mg}^{2+}, \mathrm{Na}^{+}, \mathrm{K}^{+}$) and conductivity. The results show that the average $\mathrm{pH}$ is higher than 5.6; the characteristics of the rainwater studied are of alkaline nature due to the values of $\mathrm{pH}$ found; there is an evident anthropogenic source contributing to the alkaline of rain water. In order to find possible association between ions and consequently the possible sources of pollutants correlation study was applied using the program SPSS v.12. Good correlations were found between ions $\mathrm{SO}_{4}^{2-}$ and $\mathrm{NO}_{3}^{-}$along with $\mathrm{Ca}^{2+}$ and $\mathrm{Mg}^{2+}$. The local extraction industry and surrounding aerosols might be causing of alkaline rain which may be due to the neutralization effect of particulate matter. This study represents a continuation of the studies of rainwater chemistry in the Northeast of Mexico.

\section{Keywords}

Wet Deposition, Air Quality, Monterrey, Air Pollution 


\section{Introduction}

The chemistry of rainwater has been subject to numerous investigations during the last two decades due to the increase of environmental problems caused by acid rain. Due to the rapid worldwide economic development and its associated increase in energy consumption, air pollution has risen important social concern in developing countries [1]-[3]. Wet deposition constitutes an important natural pathway for the removal of atmospheric pollutants. However, contamination of rainwater by atmospheric pollutants is of growing concern on both regional and global scale [3] [4].

The composition of the rainwater plays an important role in the transport of the soluble components of the atmosphere, which helps in understanding the contribution of atmospheric polluting agents from different sources. The chemical composition of the rainwater varies from one site to another and from one region to another, due to the influence of local sources.

The problems caused by acid rain are associated to ecological deterioration, deterioration of forests, acidification of lakes and grounds, sulfation of marble, affectation of antique buildings and monuments [5] [6]. Acid rain and its effects in the monument deterioration and buildings have reached alarming levels nevertheless this phenomenon is as old as the contamination itself, being able to be of natural or anthropogenic origin.

In Mexico, during the last two decades, a number of studies have been carried out on chemical composition of precipitation in different areas. The chemical composition of rainwater varies site to site and is conditioned to influence of local sources.

Baez and Belmont [7] conducted a study to compare water chemistry of heavy rain in 3 different areas of the country, the first was an urban area, the second one was an agricultural area and the third one was a coastal region. The parameters analyzed were: $\mathrm{pH}, \mathrm{Ca}^{2+}, \mathrm{Mg}^{2+}, \mathrm{NH}_{4}^{+}, \mathrm{SO}_{4}^{2-}, \mathrm{NO}_{3}^{-}$the highest concentrations of these inorganic ions founded in the urban and industrial areas.

Fieldwork in coastal sites was done by Bravo et al. [8], wet deposit from Puerto Morelos Quintana Roo was analyzed for $\mathrm{pH}$, conductivity and $\mathrm{Cl}^{-}, \mathrm{NO}_{3}^{-}, \mathrm{SO}_{4}^{2-}, \mathrm{Na}^{+}, \mathrm{NH}_{4}^{+}, \mathrm{K}^{+}, \mathrm{Mg}^{2+}$ and $\mathrm{Ca}^{2+}$ ion concentrations from April 1994 to December 1995. The mean [ $\mathrm{SO}_{4}^{2-}$ ] was $9.7 \mathrm{l} \cdot \mu \mathrm{Eq} \cdot \mathrm{l}^{-1}$ and for $\left[\mathrm{NO}_{3}^{-}\right]$was $11.4 \mathrm{l} \cdot \mu \mathrm{Eq} \cdot \mathrm{l}^{-1}$, the volume-weighted mean $\mathrm{pH}$ for the period was 5.45, a major component causing the slight acidity character of rain in these zone seems to be $\mathrm{H}_{2} \mathrm{SO}_{4}$.

Cerón et al. [9] report a study in samples of rain from a coastal site impacted by gas and oil industry in southeastern Mexico by using air-mass back trajectories. The study was conducted from July to November 2004 San Antonio Cardenas, Campeche. The results showed that the most abundant cations were $\mathrm{Na}^{+}, \mathrm{Cl}^{-}, \mathrm{Ca}^{2+}$ were the most abundant ions under the influence of marine aerosols and particles of crustal. The $\mathrm{NO}_{3}^{-}$and $\mathrm{SO}_{4}^{2-}$ exceeded the background level for marine sites. The mean $\mathrm{pH}$ value was 4.64 suggesting a direct anthropogenic influence over chemical composition of rainwater. From air-mass back trajectories analysis, they concluded that the main source for high levels $\mathrm{SO}_{4}^{2-} \quad$ y $\mathrm{NO}_{3}^{-}$was a sour gas recompression plant located to $10 \mathrm{~km}$ at $\mathrm{NE}$ from the study site.

Considering the importance of acid deposition and the relationship with the population growth of industrial cities, Ramírez et al. [10] commenced the rainwater chemistry studies in Monterrey Nuevo León, the third largest industrial city in Northeast of Mexico. The present work proposes a study to the understanding of the chemical composition of rainwater over an industrial zone during different months, and to determine the influence of diverse sources.

\section{Experimental Methods}

\subsection{Sampling Collection and Analysis}

Monterrey city, the third largest city in México, is located in the State of Nuevo León (lat $25^{\circ} 40^{\prime} \mathrm{N}$; long $100^{\circ} 18^{\prime} \mathrm{W}$ ). Its average altitude is $537 \mathrm{~m}$ above sea level, and has an area of $580.5 \mathrm{~km}^{2}$ (Figure 1).

Monterrey's Metropolitan Area is the third most populous city in México, it is considered a high profile center of education, tourism and business with a population of 4,000,000 in habitants with $85 \%$ in urban areas. The Metropolitan Area involves 12 cities (municipalities): Apodaca, Escobedo, García, Guadalupe, Cadereyta, Juárez, Salinas Victoria, San Nicolás de los Garza, San Pedro Garza García, Santa Catarina, Monterrey and Santiago.

The weather patterns over the area are influenced by frontal systems coming from the north of the continent. The climate is classified as semi-arid. Monterrey has a humid subtropical climate. Its weather, though reasonably 

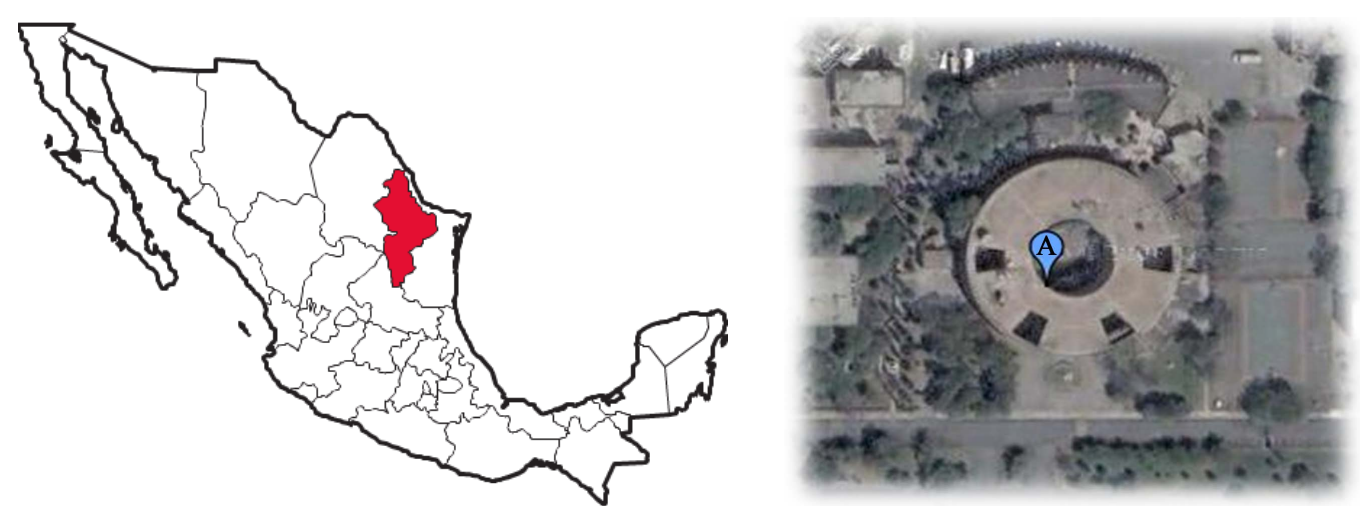

Figure 1. Nuevo leon state map.

pleasant in spring and autumn, is hot in the summer; the average of the highest temperature reaches $35^{\circ} \mathrm{C}\left(95^{\circ} \mathrm{F}\right)$ in August, with an average low of $23^{\circ} \mathrm{C}\left(74^{\circ} \mathrm{F}\right)$. Winters are cool but not cold.

The average January high is $19^{\circ} \mathrm{C}\left(67^{\circ} \mathrm{F}\right)$ and the average low in January is $8^{\circ} \mathrm{C}\left(48^{\circ} \mathrm{F}\right)$; however, temperatures below freezing are rare. Rainfall is scarce, but more prominent during May through September. Humidity in winter can be high, although without showers. Snowfall is a very rare event. The annual average precipitation is $615 \mathrm{~mm}$, temperature ranges are between $2^{\circ} \mathrm{C}$ in winter and $45^{\circ} \mathrm{C}$ in summer.

Industrial activities and vehicular fleet are common potential pollution sources. More than $60 \%$ of total emissions of $\mathrm{NO}_{\mathrm{x}}, \mathrm{CO}, \mathrm{HC}$ and $\mathrm{Pb}$ are due to vehicular fleet, and $92 \%$ of $\mathrm{SO}_{2}$ emissions are due industrial activities.

\subsection{Rain Collection}

Precipitation samples were collected at the Campus of the University of Nuevo León located in an urban area. Collection was carried out continually from March to December 2009 on an event basis with wet-only collectors according to ASTM-1989 and ASTM-1995 [11] [12].

The wet-only collector (TISCH ENVIRONMENTAL) had a lid that opened during rainfall and closed after rainfall had stopped. Standard operating procedures included routine checks and maintenance of wet-only precipitation samplers. All sampler surfaces that in contact with the rain were cleaned with deionized water between collections at the analytical laboratory.

\subsection{Chemical Analysis}

Before sampling for wet deposition, collector components were washed, soaked in distilled water for 24 hours and then rinsed with deionized water. After drying in clean enclosed areas, the components were assembled and packed individually into large plastic bags. Samples were shipped to Laboratory for analysis.

Each wet deposition sample was divided into two aliquots of $250 \mathrm{ml}$ : the first one was used to determine cations, and the other was used to analyze anions, $\mathrm{pH}$ and conductivity.

Measurements of $\mathrm{pH}$, conductivity and volume were conducted immediately on rain samples, before filtration through $0.45-\mu \mathrm{m}$ Teflon membrane filters. $\mathrm{pH}$ and conductivity measurements were obtained using a precision pH meter (TERMO ORION 290) and a conductivity meter (Hanna Instrument HI 255 combined meter) according to EPA Methods 150.1 and 120.1, respectively [13] [14].

All plastic ware and glassware used to prepare standard solutions for chemical analysis (buckets, funnels, filtration system, tubing and bottles) were rigorously washed, brushed and rinsed with distilled water. All of the materials used for sample digestion were completely immersed for $24 \mathrm{~h}$ in a $20 \%$ ultrapure nitric acid bath (J.T. Baker, AA grade), rinsed several times with deionized water type I (Hycel) and sealed into double plastic bags. Before use, all of the material was again rinsed with deionized water. Standard solutions were prepared by dilution from certified standards (J.T. Baker). All solutions were prepared with deionized water supplied by a Milli-Q-Millipore system and the standard solutions by dissolution of the $99 \%$ purity analytical grade salts. The standard solution of the anions and cations as well as blank samples were prepared with different concentrations and assigned random numbers among real samples. The quality assurance procedures included the routine running of blanks and control samples as well as replicate samples. 
$\mathrm{Cl}^{-}, \mathrm{SO}_{4}^{2-}$ and $\mathrm{NO}_{3}^{-}$were analyzed by Ion Chromatography (by ion chromatography Metrohm 882) using a conductivity detector with a 200- $\mu$ l sample loop according to EPA Method 300.0 modified [15]. For cations analysis, samples were submitted to a digestion process carried out in 100-ml Teflon closed flasks (Cole-Parmer) using autoclave equipment. $\mathrm{Na}^{+}, \mathrm{K}^{+}, \mathrm{Ca}^{2+}$ and $\mathrm{Mg}^{2+}$ were analyzed by Atomic Absorption Spectroscopy (GBC 932 AA) with the Flame Technique according to EPA Methods 7770, 7610, 7140, and 7450, respectively [16][19]. The detection limits were calculated as three times the standard deviation of six blank samples.

\subsection{Meteorological Data}

Surface meteorological data were collected using portable meteorological stations (Davies Inc., http://www.davisnet.com.au/) operating during the entire study period. Wind roses were constructed for each site using Wind Rose using READY from ARL NOAA [20]. Air-mass backward trajectories were calculated for all days with rain events. These trajectories were used to trace the origin of the air masses for the studied period. Individual trajectories for each day were estimated $24 \mathrm{~h}$ before using HYSPLIT (Hybrid Single Particle Lagrangian Integrated) from NOAA (US National Oceanic Atmospheric Administration, http://www.arl.noaa.gov/) [21]. From the calculated backward trajectories, it was observed that the prevailing winds came from the NE.

\subsection{Statistical Analysis}

Pearson's correlation analysis was applied to test the relationship among the total trace element concentrations. Factor analysis was applied to determine the factors underlying the interactions among the surveyed species. Principal components analysis (PCA), a linear method for multivariate ordination, was used to visualize the relationship among trace elements at the sampling site, focusing on the inter-element correlation coefficients [22]. The sample points and variables together form a bi-plot that displays the approximate inter-variable correlations. An ANOVA test by permutation was performed to test the significance of the factors in explaining these variations. Analysis was carried out using R Statistical Software InfoStat [23].

\section{Results and Discussion}

A total of 25 rainwater samples were collected in 25 rain events from March to December 2009. The precipitation levels ranged from 6.3 to $79.0 \mathrm{~mm}$ and were compared to the data from Integral System of Monitoring System (ISEM) Meteorological Station located $10 \mathrm{~km}$ from the sampling site.

The volume weighted mean for $\mathrm{pH}$ and conductivity, are presented in Figure 2.

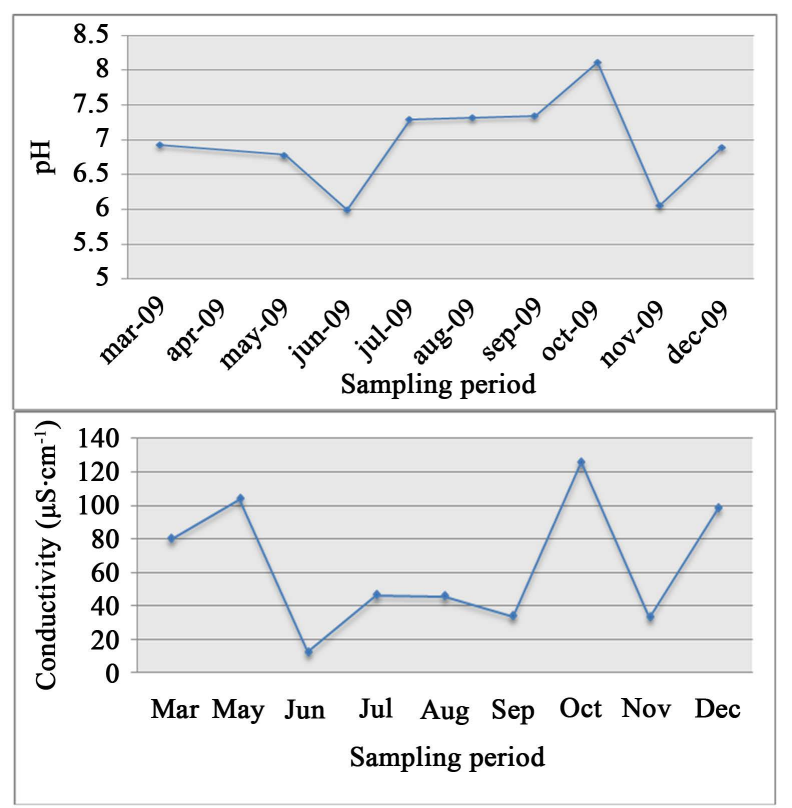

Figure 2. Volume weighted mean $\mathrm{pH}$ and conductivity. 
For wet rain samples, $\mathrm{pH}$ varied from 5.99 to 8.11 with an average of 6.96. The lowest sample $\mathrm{pH}$ values were observed in June (summer). The highest $\mathrm{pH}$ values were recorded in October (autumn).

On the other hand the conductivity and ionic concentrations decreased throughout the course of the rainy season (September). The cations and anions detected and their concentrations are showing in Figure 3.

In Figure 3 it is observed that ions found in highest concentrations were of $\mathrm{Ca}^{2+}$ followed by $\mathrm{SO}_{4}^{2-}, \mathrm{Cl}^{-}$and $\mathrm{Mg}^{2+}$. The presence of alkaline substances in the atmosphere, influence the natural composition of rainwater.

During the month of October a high concentration of ionic species in the sampling site was observed, this can be a result of the presence of thermal inversion through the season coupled with low wind speed, as a result of the zone being surrounded by mountains and the hills which prevent wind circulation.

The correlation coefficients presented in Table 1 allowed estimation of the origin of rainwater ionic species. The $\mathrm{NO}_{3}^{-}$and $\mathrm{SO}_{4}^{2-}$ ions, precursors of acid rain, show significant correlation with different ions like $\mathrm{Ca}^{2+}$, $\mathrm{Mg}^{2+}$ and $\mathrm{K}^{+}$ion the other hand the $\mathrm{NO}_{3}^{-}$only show significant correlation with $\mathrm{SO}_{4}^{2-} \quad(\mathrm{r}=0.990)$.

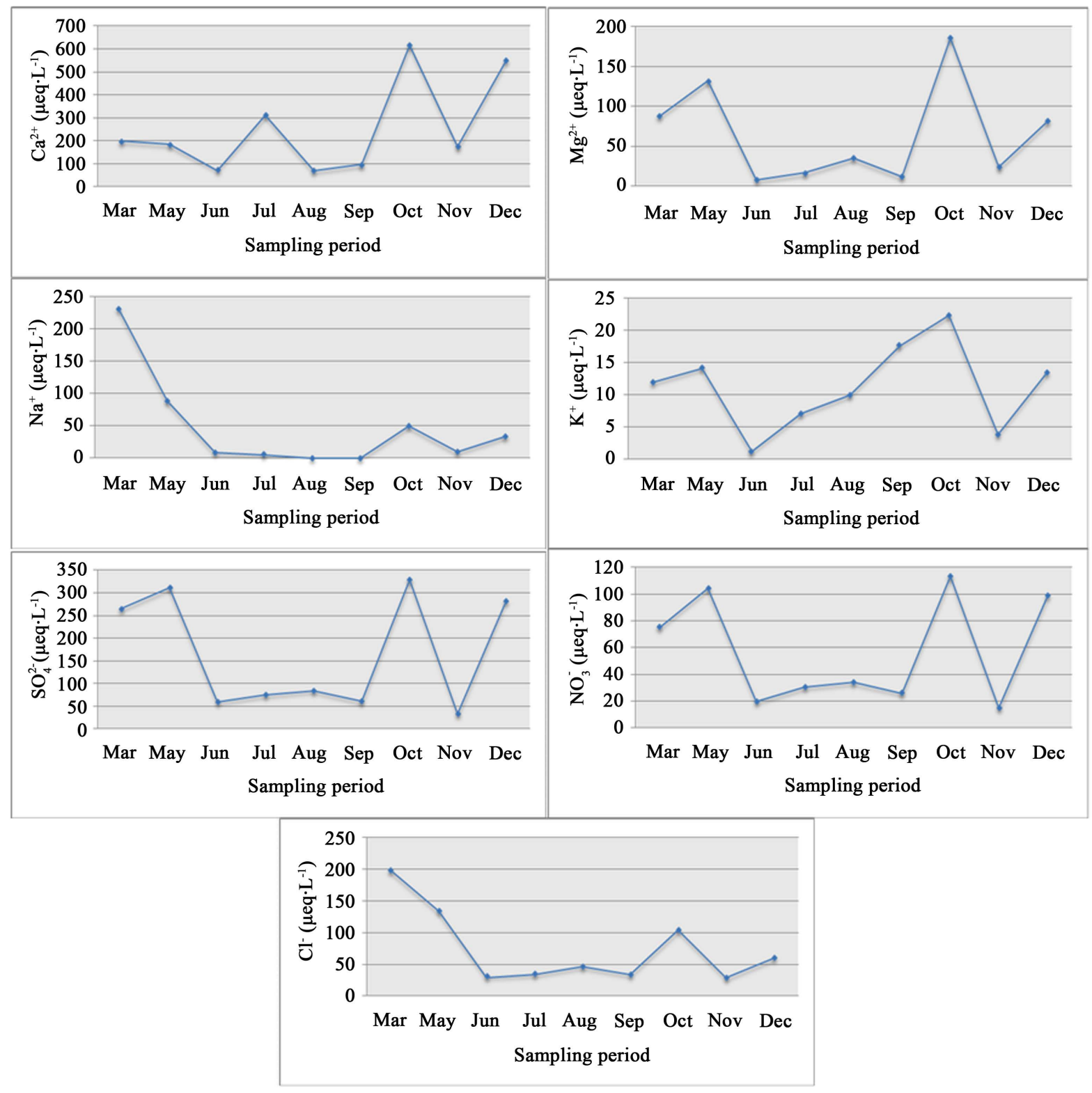

Figure 3. Cations and anions concentrations in wet rain samples. 
Table 1. Pearson correlation matrix for each measured trace elements.

\begin{tabular}{|c|c|c|c|c|c|c|c|}
\hline & $\mathrm{Mg}^{2+}$ & $\mathrm{Na}^{+}$ & $\mathrm{K}^{+}$ & $\mathrm{Ca}^{2+}$ & $\mathrm{Cl}^{-}$ & $\mathrm{NO}_{3}^{-}$ & $\mathrm{SO}_{4}^{2-}$ \\
\hline $\mathrm{Mg}^{2+}$ & & 0.452 & $0.717^{* *}$ & $0.668^{* *}$ & $0.663^{* *}$ & $0.932^{* *}$ & $0.923^{* *}$ \\
\hline $\mathrm{Na}^{+}$ & & & 0.214 & 0.062 & $0.955^{* *}$ & 0.482 & $0.598^{* *}$ \\
\hline $\mathrm{K}^{+}$ & & & & $0.540^{* *}$ & 0.47 & $0.702^{* *}$ & $0.663^{* *}$ \\
\hline $\mathrm{Ca}^{2+}$ & & & & & 0.167 & $0.711^{* *}$ & $0.659^{* *}$ \\
\hline $\mathrm{Cl}^{-}$ & & & & & & $0.667^{* *}$ & $0.757^{* *}$ \\
\hline $\mathrm{NO}_{3}^{-}$ & & & & & & & $0.990^{* *}$ \\
\hline $\mathrm{SO}_{4}^{2-}$ & & & & & & & \\
\hline
\end{tabular}

${ }^{* *}(p<0.01)$.

A significant correlation between $\mathrm{Ca}^{2+}$ and $\mathrm{Mg}^{2+}(\mathrm{r}=0.668)$ can be observed thus explains the variation between $\mathrm{pH}$ slightly acidy and slightly alkaline that were detected in the samples. $\mathrm{SO}_{4}^{2-}$ - $\mathrm{NO}_{3}^{-}$had good correlation $(r=0.990)$ indicating that these ions could have sources in common, probably combustion sources. A good correlation between $\mathrm{Cl}^{-}$and $\mathrm{Na}^{+}$indicates that the study area was probably influenced by inputs of maritime air from marine aerosols. $\mathrm{Ca}^{2+}$ and $\mathrm{Mg}^{2+}$ showed a moderate correlation, indicating that at least partially these ions could be originated from common sources, such as soil particles and marine aerosol.

High levels of calcium suggest a significant contribution from crustal sources; this was expected because calcisols are the dominant soil type in Monterrey Area [10] [24]. High levels of chloride and sodium were found during spring season (March-May) and during the norths season (October) when winds blew from ENE (from the Gulf of Mexico) bringing maritime air enriched with these ions. This behavior has been reported for other authors, who have found an abrupt increase of sea spray droplets when wind speed increases as hurricanes approach the coast. This was also observed by Padilla et al. [25] in Huatulco Bay and Manzanillo, Colima in Mexico. Cerón and collaborators [21] found high levels of sodium and chloride in Monterrey after the passage of the Hurricane "Alex" in 2010. This could explain the unexpected high levels of these ions at this site, as Monterrey is not a coastal site.

The Principal Component Analysis (PCA) has been used for extracting factors controlling the major ion chemistry of atmospheric deposition and to identify the possible source of the major ions in wet atmospheric deposition [26] [27]. The data matrix of 8 variables ( $\mathrm{pH}, \mathrm{SO}_{4}^{2-}, \mathrm{NO}_{3}^{-}, \mathrm{Cl}^{-}, \mathrm{NH}_{4}^{+}, \mathrm{Ca}^{2+}, \mathrm{K}^{+}, \mathrm{Mg}^{2+}, \mathrm{Na}^{+}$) and 25 observations were used in the present factor analysis. Principal components with eigenvalues $>0.7$ were extracted from the principal factor matrix (Table 2).

$\mathrm{pH}$ was closely related with $\mathrm{Ca}^{2+}$ (Figure 4). This analysis shows a very close relationship between $\mathrm{Ca}^{2+}$, $\mathrm{Mg}^{2+}$ and $\mathrm{K}^{+}$, which agrees with the neutralisation effect of these cations and suggests the important role of crustal sources in the neutralisation process at this site. $\mathrm{Na}^{+}$and $\mathrm{Cl}^{-}$show a close relation indicating that these ions could be originated from a common source (inputs of maritime air coming from Gulf of Mexico during spring and and norths seasons). $\mathrm{NO}_{3}^{-}$and $\mathrm{SO}_{4}^{2-}$ showed a very good relation, indicating that these ions could have common sources (combustion sources). Table 2 shows the factor loading of the two major principal components, which represent together $83.1 \%$ of the cumulative variance percentage. High loadings were found for $\mathrm{SO}_{4}^{2-}, \mathrm{NO}_{3}^{-}, \mathrm{Cl}^{-}, \mathrm{Mg}^{2+}, \mathrm{Na}^{+}$and $\mathrm{K}^{+}$indicating that PC1 was influenced by anthropogenic emissions and maritime air masses coming from ENE.

\section{Meteorological Analysis}

Monthly Meteorological conditions are shown in Table 3. Prevalent winds blew from East-Northeast, maximum temperatures were registered during July with a mean value of $30.1^{\circ} \mathrm{C}$ and minimum values of temperature were registered during December with a mean value of $12^{\circ} \mathrm{C}$. Wind speed ranked from 1.5 to $2.8 \mathrm{~m} / \mathrm{s}$ as it can be observed in Table 3.

According to Table 3, in this urban site, low wind speed values were registered due to the Metropolitan Area of Monterrey is surrounded by hills and mountains which act as natural barriers that contributed to slow down 


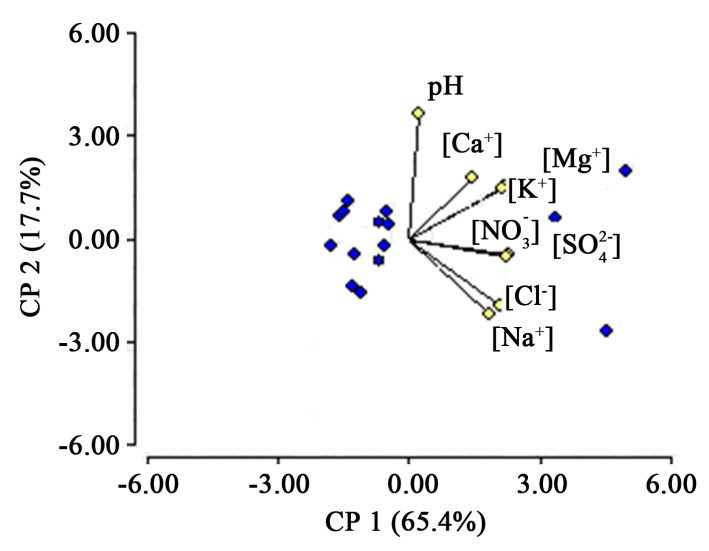

\begin{abstract}
Biplot(1,2)
Biplot(1,2)-Variables

Figure 4. Principal component analysis: Ordination biplot for wet deposition samples collected at the Metropolitan Area of Monterrey.
\end{abstract}

Table 2. Factor loading of the principal components for the data set of wet deposition in the study site using PCA.

\begin{tabular}{ccc}
\hline Variables & $\underline{\mathrm{CP} 1}$ & $\underline{\mathrm{CP} 2}$ \\
\hline $\mathrm{pH}$ & 0.11 & $\mathbf{0 . 7 9}$ \\
{$\left[\mathrm{SO}_{4}^{2-}\right]$} & $\mathbf{0 . 9 7}$ & -0.09 \\
{$\left[\mathrm{NO}_{3}^{-}\right]$} & $\mathbf{0 . 9 4}$ & -0.11 \\
{$\left[\mathrm{Cl}^{-}\right]$} & $\mathbf{0 . 8 8}$ & -0.42 \\
{$\left[\mathrm{Ca}^{2}\right]$} & 0.62 & $\mathbf{0 . 3 9}$ \\
{$\left[\mathrm{Mg}^{2}\right]$} & $\mathbf{0 . 9 1}$ & 0.33 \\
{$\left[\mathrm{Na}^{+}\right]$} & $\mathbf{0 . 7 7}$ & -0.47 \\
{$\left[\mathrm{~K}^{+}\right]$} & $\underline{\mathbf{0 . 9 1}}$ & $\underline{\mathbf{0 . 3 2}}$ \\
\hline
\end{tabular}

Table 3. Prevalent meteorological conditions in the study site during the sampling period.

\begin{tabular}{ccccc}
\hline Month & Sampling total volume $(\mathrm{mm})$ & Mean Temperature $\left({ }^{\circ} \mathrm{C}\right)$ & Mean Wind Speed $(\mathrm{m} / \mathrm{s})$ & Wind Direction Frequency \\
\hline March 2009 & 6.3 & 19.8 & 2.2 & ENE \\
April 2009 & 0.0 & 24.7 & 2.5 & ENE \\
May 2009 & 16.4 & 26.7 & 2.5 & ENE \\
June 2009 & 12.0 & 28.6 & 2.8 & E \\
July 2009 & 56.9 & 30.1 & 2.6 & E \\
August 2009 & 21.0 & 29.2 & 2.7 & E \\
September 2009 & 79.0 & 24.9 & 2.0 & ENE \\
October 2009 & 16.2 & 22.4 & 1.8 & NNE \\
November 2009 & 26.2 & 18.4 & 1.5 & 1.6 \\
December 2009 & 24.5 & 13.0 & & NE \\
\hline
\end{tabular}

wind flux. During summer (July-September) it can be observed an increase in the wind speed values; these conditions could contribute to high air pollutants dispersion. During the dry season (February-May), the influence of anti-cyclonic systems in this area causes a great atmospheric stability with a minimum dispersion and an increase in the air pollutants concentrations. In order to know the origin of air masses, wind roses and $24 \mathrm{~h}$ back trajectories of air masses were constructed for each sampling day. This analysis let us to know the probable origin of the air pollutants present in wet deposition samples and the location of the possible sources. Figures 5(a)-(i) shows typical wind roses for each month and it can be observed that most of the time, winds were blowing from E-NE. 
gdas1.mar09.w2 Wind Rose

Latitude: 25.73 Longitude: -100.31

Level: $10 \mathrm{~m}$
DATA INITIAL TIME: 08 MAR 2009 00Z CALCULATION STARTED AT: 12 MAY $200900 \mathrm{Z}$ DATA INITIAL TIME: 08 MAR 2009 00Z CALCULATION STARTED AT: 12 MAY 2009007 NEADY Web Server

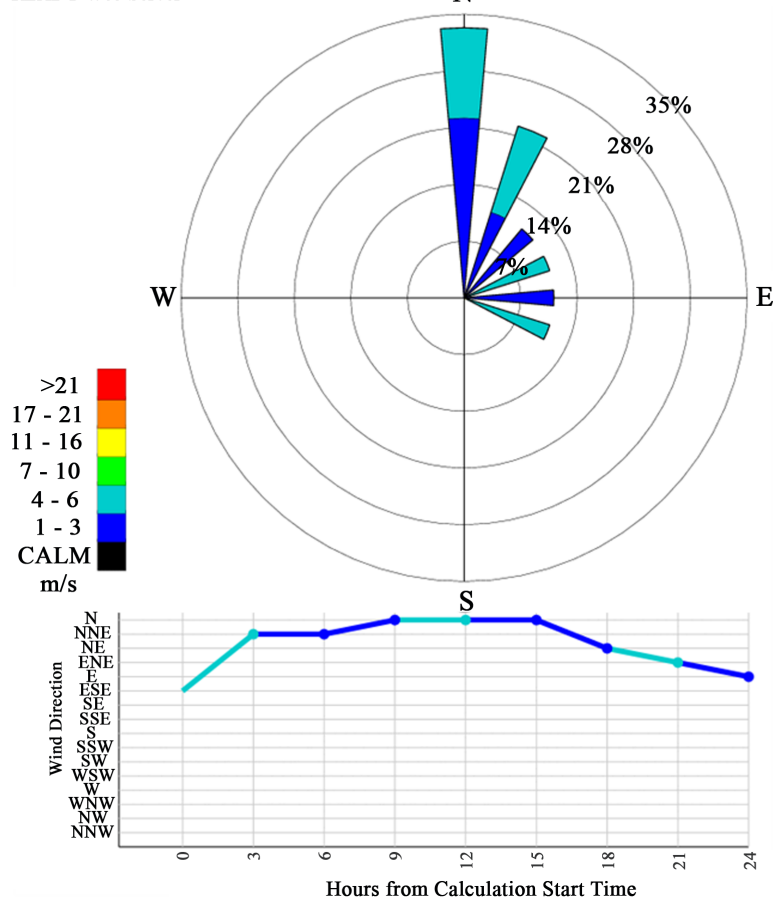

(a)

gdas1.jun09.w1 Wind Rose

Latitude: 25.73 Longitude: -100.31

Level: $10 \mathrm{~m}$
DATA INITIAL TIME: 01 JUN 2009 00Z CALCUATION STARTED AT: 03 JUN $200900 \mathrm{Z}$
NOAA AIR RESOURCES LABORATORY CALCULATION ENDED AT: 04 JUN $200900 \mathrm{Z}$ NOAA AIR RESOURCES LABORATORY CALCULATION ENDED AT: 04 JUN 2009 00Z READY Web Server

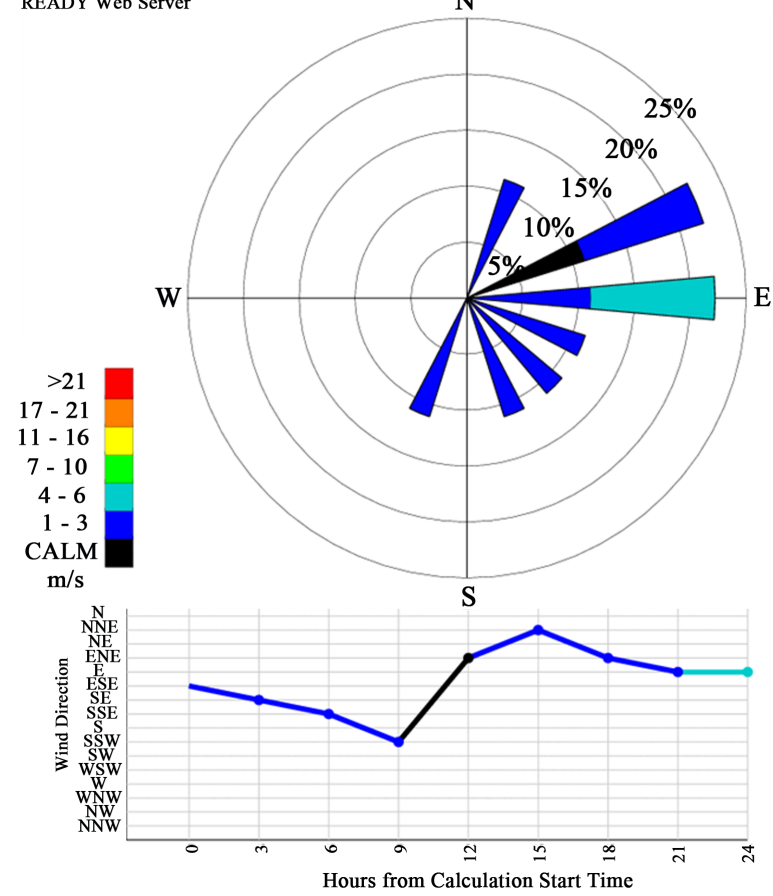

(c) gdas1.may09.w5 Wind Rose

Latitude: 25.73 Longitude: -100.31

$$
\text { Level: } 10 \mathrm{~m}
$$

Level: $10 \mathrm{~m}$
DATA INITIAL TIME: 29 MAY 2009 00Z CALCULATION STARTED AT: 29 MAY $200900 \mathrm{Z}$ NOAA AIR RESOURCES LABORATORY CALCULATION ENDED AT: 30 MAY 2009 00Z NOAA AIR RESOURCES LABORATORY CALCULATON

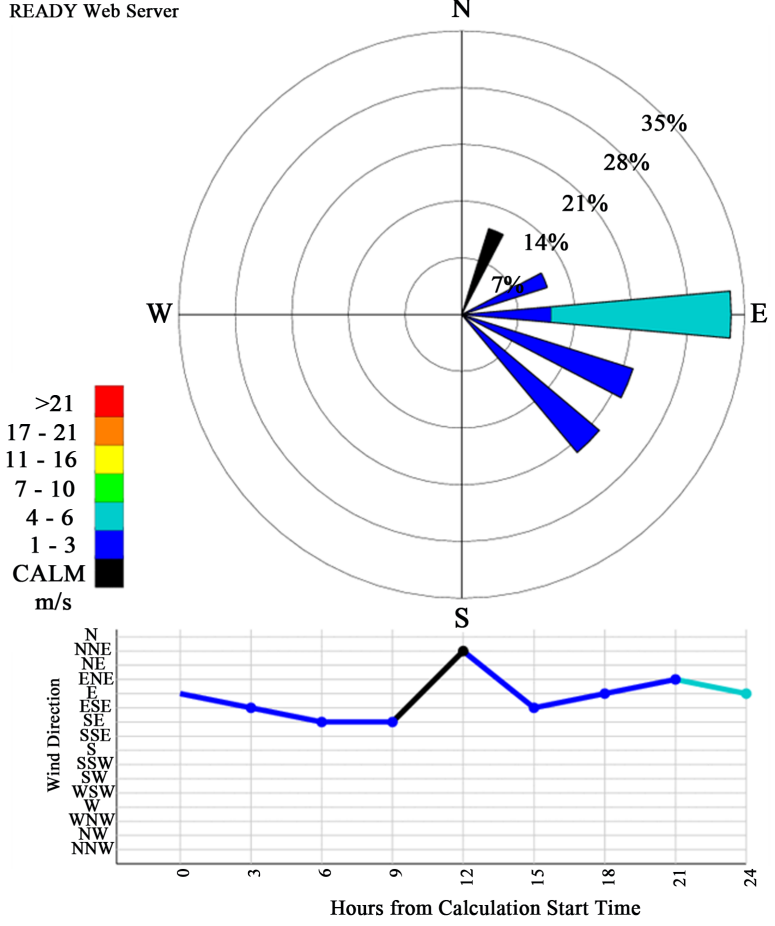

(b)

gdas1.ju109.w51 Wind Rose Latitude: 25.73 Longitude: -100.31 DATA INITIAL TIME: 29 JUN 2009 LeZ

DATA INITIAL TIME: 29 JUN 2009 00Z CALCULATION STARTED AT: 30 JUL $200900 \mathrm{Z}$ NOAA AIR RESOURCES LABORATORY CALCULATION ENDED AT: 31 JUL 2009 00Z
READY Web Server

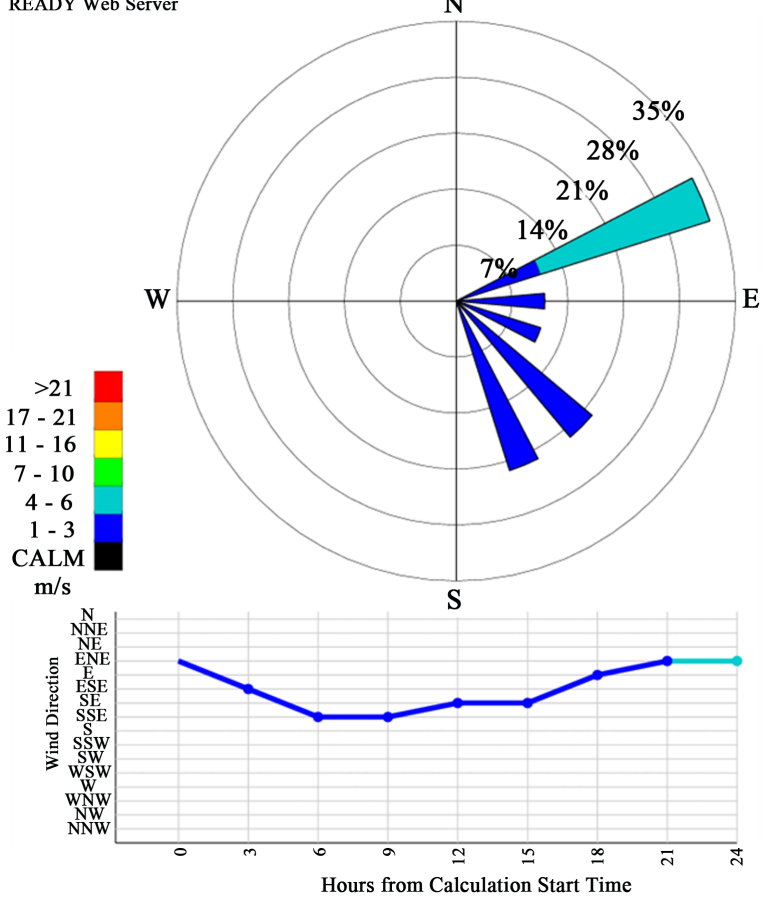

(d) 
gdas1.aug09.w5 Wind Rose

Latitude: 25.73 Longitude: -100.31

DATA INITIAL TIME: 29 AUG 2009 00Z CALCULATION STARTED AT: 31 AUG $200900 \mathrm{Z}$ NOAA AIR RESOURCES LABORATORY CALCULATION STARTED AT: 01 SEP $200900 Z$
READY Web Server

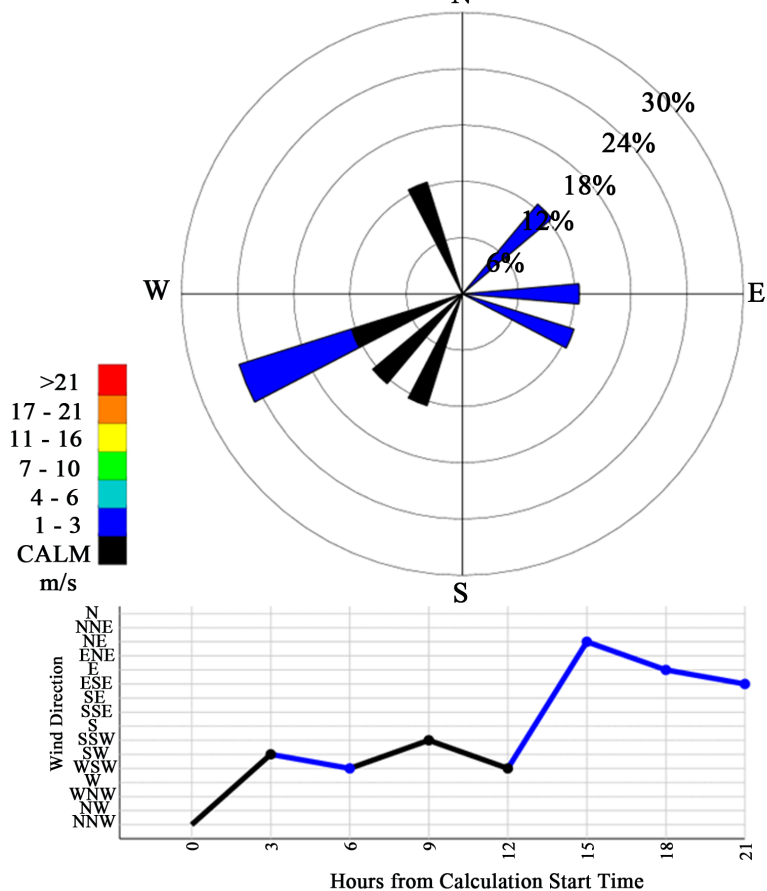

(e)

gdas1.oct09.w3 Wind Rose

Latitude: 25.73 Longitude: -100.31 Level:10 m DATA INITIAL TIME: 15 OCT 2009 00Z CALCULATION STARTED AT: 16 OCT $200900 \mathrm{C}$
NOAA AIR RESOURCES LABORATORY CALCULATION STARTED AT: 17 OCT 2009 00Z READY Web Server

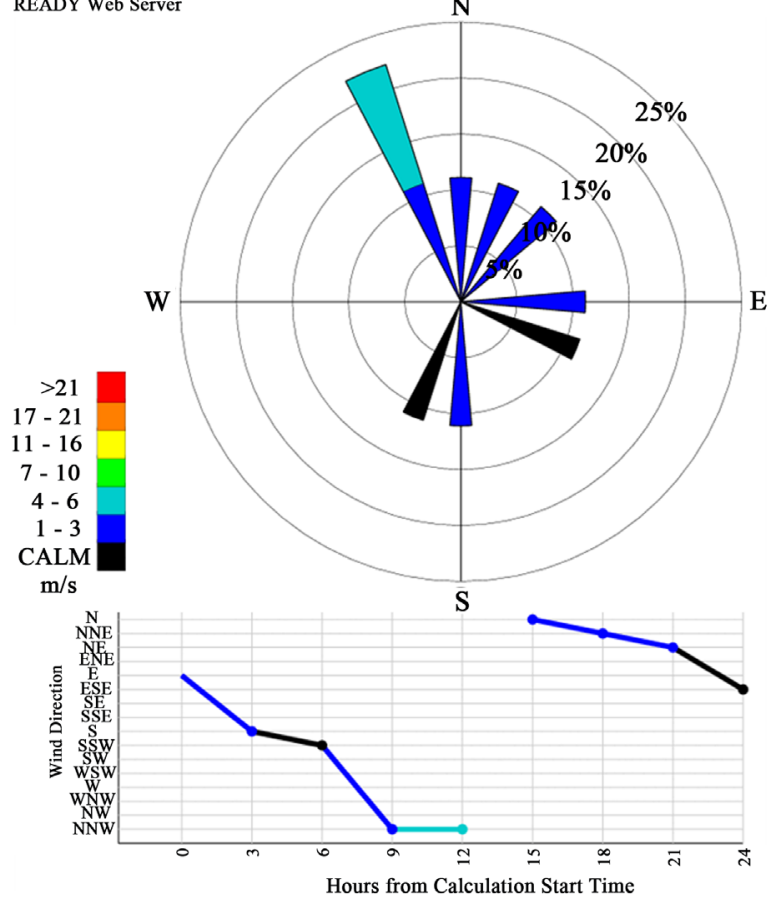

(g) gdas1.sep09.w3 Wind Rose

Latitude: 25.73 Longitude: -100.31

Level: $10 \mathrm{~m}$
CALCUATION STARTED AT: 19 SEP $200900 \mathrm{Z}$ READY Web Server

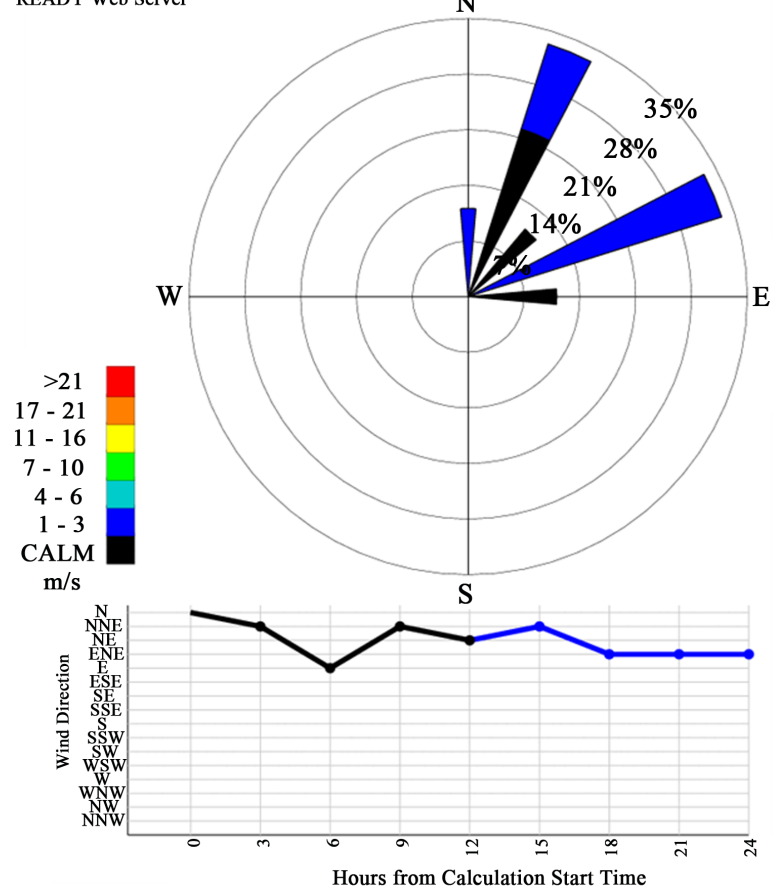

(f)

gdas1.nov09.w4 Wind Rose

Latitude: 25.73 Longitude: -100.31

Level:10 m
DATA NITIAL TIME. 22 NOV 2009007 CALCULATION STARTED AT: 24 NOV $200900 Z$ DATA INITIAL TIME: 22 NOV 2009 00Z CALCULATION STARTED AT: 24 NOV $200900 Z$ READY Web Server

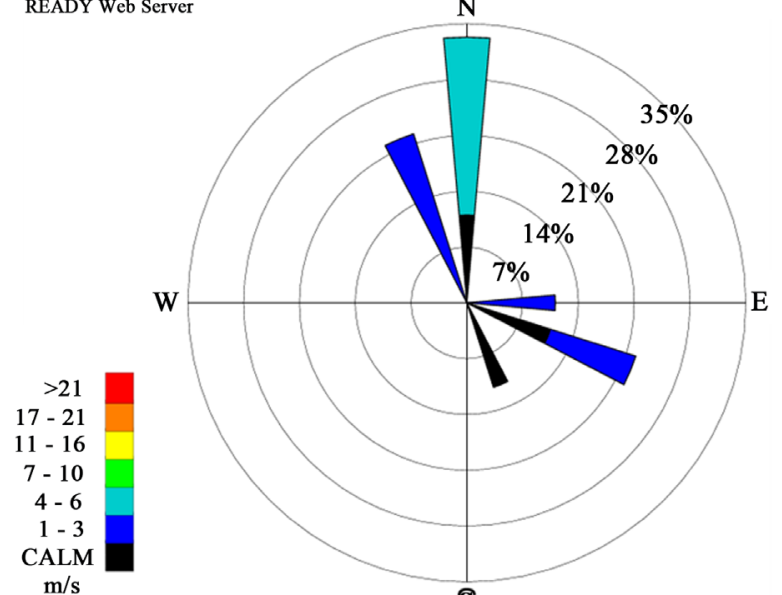

$\mathrm{m} / \mathrm{s}$

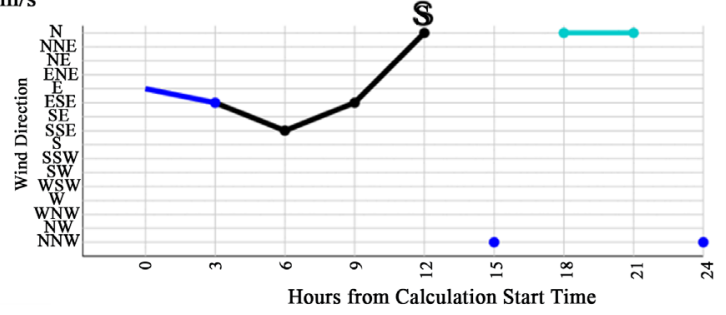

(h) 


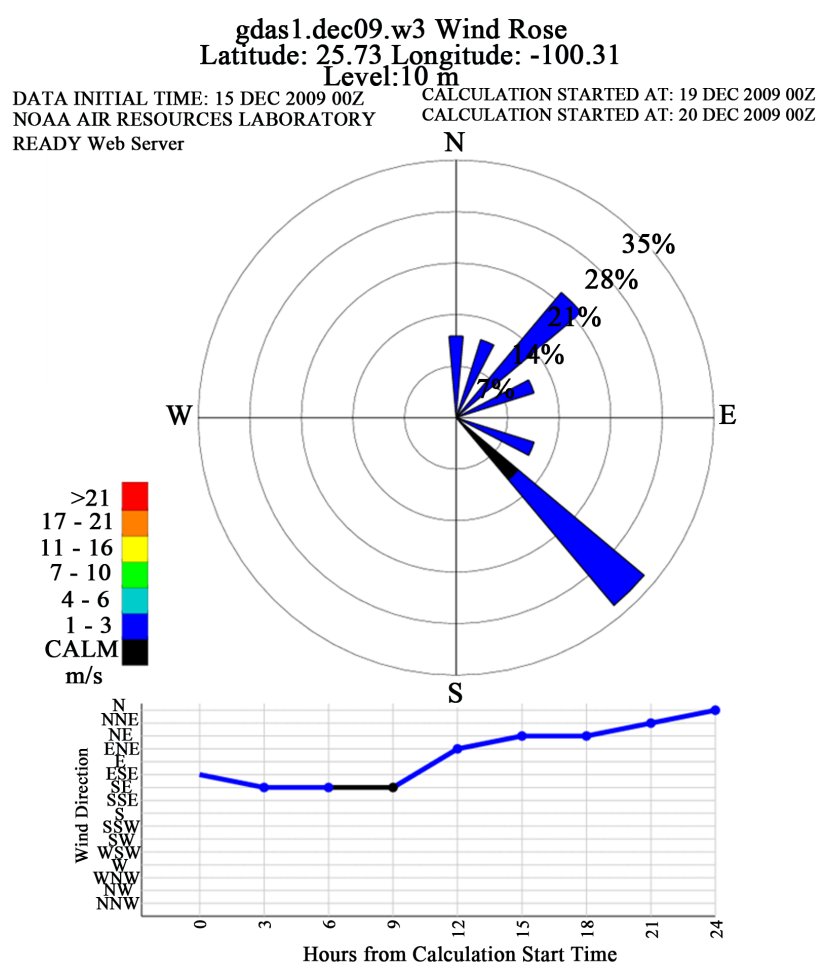

(i)

Figure 5. Typical wind roses for each month during the sampling period. (a) March 2009 (12/03/2009); (b) May (29/05/2009); (c) June (3/06/2009); (d) July (30/07/2009); (e) August (31/08/2009); (f) September (19/09/2009); (g) October (16/10/2009); (h) November (24/11/2009); (i) December (19/12/2009).

According to the meteorological analysis, sources located at the East -Northeast of the study site could influence the air pollutants concentrations (Apodaca and Esobedo municipalities) in a local scale and from the Gulf of Mexico in a regional scale). In Apodaca is located the Monterrey International Airport, as well as numerous industries involved in manufacturing of industrial lubrication additives, fertilizers, insecticides, steel products and so on. Also important roads with high vehicular traffic such as Apodaca-Dr Gonzalez highway, Monterrey -Laredo highway and Monterrey-Miguel Aleman road. In the municipality of Escobedo, Nuevo Leon numerous manufacturing and service industries, agricultural and livestock activities, as well as the General Mariano Escobedo Industrial Park (one of the most important in the region) are located. All these sources (vehicular and industrial) could contribute to the air pollutants levels found in this site.

\section{Conclusion}

A whole study of the chemical composition rainwater over an industrial zone located at the northeast of Mexico was carried out from March to December, 2009. A seasonal variation was found and highest values were found for $\mathrm{Ca}^{2+}$ and $\mathrm{SO}_{4}^{2-}$. During the autumn season (October), the influence of a thermal inversion was evident, this condition caused that all the ionic species concentrate in the atmosphere of the study site due to low wind speed and a poor dispersion. During spring (March to May) and during norths season (October) high values of sodium and chloride were found, probably due to inputs of maritime air coming from the Gulf of Mexico. Mean $\mathrm{pH}$ value was within the alkaline range, it could be explained due to the presence of a cement industry, whose emissions could neutralize sulfate and nitrate ions in the study site, mainly during the autumn season. Calcium levels were high suggesting a significant contribution from sources of crustal material (re-suspended soil particles: calcisols are the dominant soil type in the study area; and emissions from a cement industry). Influence of sources located at Apodaca and Mariano Escobedo municipalities (a local scale) and from the Gulf of Mexico (at a regional scale) located at the East-Northeast (ENE) was evident. Mean nitrate and sulfate values are comparable to those obtained in other mega cities around the world, considering that Monterrey city is the third largest city in 
Mexico with the corresponding increase in the fuel consumption, industrial development and vehicular fleet, resulting in high emissions of $\mathrm{SO}_{2}$ and $\mathrm{NO}_{\mathrm{x}}$, forming high concentrations of acids in the study site.

\section{Acknowledgements}

The authors thank Universidad Autónoma de Nuevo León and Universidad Autónoma del Carmen for financial support of this work.

\section{References}

[1] Bennett, E.P. (1998) Acidic Deposition: The Interplay of Regulatory Control Programs. Environmental Science \& Policy, 1, 239-247. http://dx.doi.org/10.1016/S1462-9011(98)00031-8

[2] Hara, H. (1998) Acid Deposition Chemistry in Asia, Europe and North America. Progress in Nuclear Energy, 32, 331338. http://dx.doi.org/10.1016/S0149-1970(97)00093-0

[3] Chandra Mouli, P., Venkata Mohan, S. and Jayarama Reddy, S. (2005) Rainwater Chemistry at a Regional Representative Urban Site: Influence of Terrestial Sources on Ionic Composition. Atmospheric Environment, 39, 999-1008. http://dx.doi.org/10.1016/j.atmosenv.2004.10.036

[4] Singh, A.K., Mondal, G.C., Kumar, S., Singh, K.K., Kamal, K.P. and Sinha, A. (2007) Precipitation Chemistry and Occurrence of Acid Rain over Dhanbad, Coal City of India. Environmental Monitoring and Assessment, 125, 99-110. http://dx.doi.org/10.1007/s10661-006-9243-4

[5] Samara, C., Tsitouridou, R. and Balafoutis, Ch. (1992) Chemical Composition of Rain in Thessaloniki, Greece, in Relation to Meteorological Conditions. Atmospheric Environment, 26B, 359-367. http://dx.doi.org/10.1016/0957-1272(92)90011-G

[6] Galloway, J.N. (2001) Acidification of the World: Natural and Anthropogenic. Water, Air, \& Soil Pollution, 130, 17-24. http://dx.doi.org/10.1023/A:1012272431583

[7] Baez, A. and Belmont, R. (1987) Comparative Study of the Chemical Composition of Rain of Three Different Zones in México. Revista Internacional de Contaminacion Ambiental, 3, 25-36.

[8] Bravo, H., Saavedra, M.I.R., Sánchez, P.A., Torres, R.J. and Granada, L.M.M. (2000) Chemical Composition of Precipitation in a Mexican Maya Region. Atmospheric Environment, 34, 1197-1204. http://dx.doi.org/10.1016/S1352-2310(99)00305-2

[9] Cerón Bretón, R.M., Cerón Bretón, J.G., Muriel, M. and Cárdenas, B. (2008) Identification of Ion Source in Rainwater of a Coastal Site Impacted by the Gas and Oil Industry in the Southeast of Mexico. Global NEST Journal, 1, 92-100.

[10] Ramírez Lara, E., Miranda Guardiola, R., Balderas Rentería, I., Gracia Vásquez, Y., Bravo Álvarez, H., Sosa Echeverría, R., Alarcón Jiménez, A. and Kahl, J. (2010) Chemical Composition of Rainwater in Northeastern of México. Atmósfera, 23, 213-224.

[11] ASTM D 5012-89, Standard Guide of Materials Used for Preparation of Materials Used for the Collection and Preservation of Atmospheric Wet Deposition.

[12] ASTM D 5111-95, Standard Guide for Choosing Locations and Sampling Methods to Monitor Atmospheric Deposition at Non Urban Locations.

[13] US EPA, Method 150.1 (1982) Methods for Chemical Analysis of Water and Wastes. US Environmental Protection Agency. Office of Research and Development, pH in Water by Electrometric Method.

[14] US EPA, Method 120.1 (1982) Methods for Chemical Analysis of Water and Wastes. US Environmental Protection Agency. Office of Research and Development, Specific Conductance in Water.

[15] US EPA, Method 300.0 (1993) Anions EPA Method. US Environmental Protection Agency. Office of Research and Development, Nitrate, Sulphate and Chloride by IC, 600/4-79-020 Report.

[16] US EPA, Method 7770 (1986) Methods for Chemical Analysis of Water and Wastes. US Environmental Protection Agency. Office of Research and Development, Sodium-AA, Direct Aspiration SW-846 Chapter 3.3.

[17] US EPA, Method 7610 (1986) Methods for Chemical Analysis of Water and Wastes. US Environmental Protection Agency. Office of Research and Development, Potasium-AA, Direct Aspiration SW-846 Chapter 3.3.

[18] US EPA, Method 7140 (1986) Methods for Chemical Analysis of Water and Wastes. US Environmental Protection Agency. Office of Research and Development, Calcium-AA, Direct Aspiration SW-846 Chapter 3.3.

[19] US EPA, Method 7450 (1986) Methods for Chemical Analysis of Water and Wastes. US Environmental Protection Agency. Office of Research and Development, Magnesium-AA, Direct Aspiration SW-846 Chapter 3.3.

[20] READY. ARL. NOAA. http://www.arl.noaa.gov 
[21] Draxler, R.R. and Hess, G.D. (1997) Description of the HYSPLIT-4 Modeling System. NOAA Technical Memorandum ERL ARL-224, NOAA Air Resources Laboratory, Silver Spring, 1-24.

[22] Davis, J.C. (1986) Statistics and Data Analysis in Geology. John Wiley, New York.

[23] Di Rienzo, J.A., Casanoves, F., Balzarini, M.G., Gonzalez, L., Tablada, M. and Robledo, C.W. (2010) InfoStat versión 2010. Grupo InfoStat, FCA, Universidad Nacional de Córdoba, Córdoba. http://www.infostat.com.ar

[24] Cerón-Bretón, R.M., Cerón-Bretón, J.G., Aguilar-Ucán, C., Ramírez-Lara, E., Ortínez-Álvarez, J.A., MontalvoRomero, C. and Carballo-Pat, C.G. (2014) Wet Deposition Fluxes and Related Atmospheric Chemistry at Three Sites in Mexico. Open Journal of Air Pollution, 3, 1-9. http://dx.doi.org/10.4236/ojap.2014.31001

[25] Padilla, H.G., Belmont, R., Torres, M.B. and Báez, A.P. (2000) Hurricanes Pauline and Nora Rainwater Chemical Composition. Canadian Journal of Earth Sciences, 37, 569-578. http://dx.doi.org/10.1139/e99-114

[26] Seto, S., Oohara, M. and Ikeda, Y. (2000) Analysis of Precipitation Chemistry at a Rural Site in Hiroshima Prefecture, Japan. Atmospheric Environment, 34, 621-628. http://dx.doi.org/10.1016/S1352-2310(99)00166-1

[27] Tang, A., Zhuang, G., Wang, Y., Yuan, H. and Sun, Y. (2005) The Chemistry of Precipitation and Its Relation to Aerosols in Beijing. Atmospheric Environment, 39, 3397-3406. http://dx.doi.org/10.1016/j.atmosenv.2005.02.001 